\title{
BASIC DETERMINANTS OF PUBLIC SUPPORT FOR TURKEY'S EU MEMBERSHIP WITH RESPECT TO COGNITIVE LEVEL OF RESPONDENTS
}

\author{
Sefer YILMAZ ${ }^{1}$ \\ Azmi YALÇIN ${ }^{2}$
}

\begin{abstract}
In this paper, basic determinants of public support for Turkey's EU membership were analyzed. The data utilized for the study was obtained from Eurobarometer Surveys, and covered a period of nine years, from 2010 to 2018. Unlike earlier studies in which the data was usually collected within a span of a few years, this study, however, consisted of a public opinion aggregate that stretched up to almost a decade. Besides, different from previous studies, in this, effects of determinants were investigated with respect to EU-awareness level of the respondents. Our findings suggest, in line with literature, that the strongest determinant regarding support for integration, was found to be the "expected benefit", and that the factor "fear of loss of cultural identity" seemed to have a meaningful and negative impact on support for EU membership. However, different from similar studies, the findings do suggest that, as respondents' cognitive level increased, the effects of "loss of cultural identity" on public support decreased to a level where it became statistically insignificant. On the contrary, the impacts of "expected benefit" and "trust in the EU" variables were detected to increase as the cognitive level of respondents rises. No meaningful relationship was observed between the factors of "age-gender-trust in government" and the dependent variable.

Keywords: Organizations, International Organizations, European Union, Public Opinion
\end{abstract}

\section{KATILIMCILARIN BILISSSEL DÜZEYLERINE GÖRE TÜRKIYY'NIN AB ÜYELIGĞININ TEMEL BELIRLEYICILERI}

ÖZ

$\mathrm{Bu}$ makalede, Türkiye'nin $\mathrm{AB}$ üyeliğine yönelik kamuoyu desteğinin unsurları incelenmektedir. Çalışmada kullanılan veriler 2010-2018 dönemindeki dokuz yıla ait Eurobarometer anketlerinden elde edilmiştir. Sadece birkaç yılı kapsayan önceki çalışmalarda olduğunun aksine, bu çalışmada neredeyse on yıla yakın bir döneme ait kamuoyu tutumları kapsama alınmıştır. Ayrıca, yine bu çalışmada, öncekilerden farklı olarak, tutum belirleyicilerinin etkileri, katılımcıların $\mathrm{AB}$ farkındalık düzeyleri bakımından ele alınmıștır. Bulgular, akademik yazının paralelinde, bütünleşmeye destek konusunda en güçlü belirleyicinin "beklenen fayda" olduğunu ve "kültürel kimliğinin kaybolacağı korkusunun" bütünleşme üzerinde anlamlı ve negatif bir etkisinin bulunduğunu göstermiștir. Ancak, benzer çalışmalardan farklı olarak, bulgular, katılımcıların biliş düzeyleri yükseldikçe, bu etkinin istatistiksel olarak anlamlı olmayacak bir düzeye indiğini ortaya koymuştur. Tersine, "beklenen fayda" ve "AB'ye güven" değişkenlerinin, katılımcıların biliş düzeyi arttıkça yükseldiği görülmüştür. Yaş, cinsiyet, hükümete güven faktörleriyle bağımlı değişken arasında herhangi bir ilişki saptanmamıştır. Anahtar Kelimeler: Örgütler, Uluslararası örgütler, Avrupa Birliği, Kamuoyu

\footnotetext{
${ }^{1}$ Doç. Dr., Çukurova Üniversitesi, İktisadi İdari Bilimler Fakültesi, İşletme Bölümü, seferyilmaz@cu.edu.tr, ORCID: 0000-0001-8784-2777.

2 Prof. Dr., Çukurova Üniversitesi, İktisadi İdari Bilimler Fakültesi, İşletme Bölümü, azmiyalcin@cu.edu.tr, ORCID: 0000-0002-9323-3350

Received/Geliș: 12/06/2019 Accepted/Kabul: 06/09/2019, Research Article/Araștırma Makalesi

Cite as/Alıntı: Yılmaz,S., Yalçın, A. (2019), "Basic Determinants of Public Support for Turkey's EU Membership with Respect to Cognitive Level of Respondents", Çukurova Üniversitesi Sosyal Bilimler Enstitüsü Dergisi, cilt 28, sayı 2, s.225-240.
} 


\section{Introduction}

Public opinion is commonly assumed to be shaping the process of European Union (EU) integration deeply. It is argued to influence the progress of accession talks in EU candidate countries directly (Çarkoğlu, 2003, p.171). While on one hand public support for EU membership may provide significant contributions to the accession process, on the other hand, lack of such kind of a support might hinder the membership efforts. Politicians have come to realize this significant role of public opinion in determining the nature of European integration particularly with the rejection of EU constitution and EU membership in various circumstances such as the Maastricht referenda in France and Denmark and the rejection of membership in Norway 1972, 1994, and in Switzerland 1992 (Gabel, 1998; Cichowski, 2000, p.1244; Slomczynski and Shabad, 2003, p.504; Ehin, 2001, p.31-32).

Until recently, numerous public opinion surveys, which had been conducted for the last two decades, showed that Turkish population had mostly been in favor of the EU membership of Turkey, despite experienced multiple up and downs and abundant disappointments (Çarkoğlu, 2003; Şenyuva, 2006, 2009; Kentmen 2008; Çarkoğlu and Kentmen, 2011). This fact alone should have been regarded as the firm and steady will of Turkish community being a part of the EU, by the European politicians. However, this invaluable affirmative disposition of a nation was ignored. Instead of taking the advantage of this situation to consolidate the Europeanization, politicians opted to miss this invaluable opportunity and helped Euroscepticism flourish among Turkish population.

As a consequence, at this stage, Turkish public opinion seemed to be moving away from the EU sharply. The image of the EU is getting worse day by day. The EU is apparently suffering from a credibility problem in the eyes of Turkish public opinion today. Various factors are believed to be underlying behind this negative development. One of the most significant factors underlying this loss of credibility is considered to be EU's failure to meet its promises for instance, with respect to the revision of the status of Northern Cyprus in the wake of the Annan Plan (Misiągiewicz, 2015, p.62) and more recently, regarding to the visa liberalization as a consequence of 18 March 2016 agreement between Turkey and the EU. The articulation of other types of models such as "privileged partnership", reservation on multiple chapters and even suspension of accession talks on every occasion, raised doubts among Turkish public about the goodwill of the EU side.

For example, short after the coup attempt in July 2016, the European Parliament (EP) called for a halt to talks arguing so-called breaches in the rule of law in Turkey, in November 2016. Austria and Denmark suggested the accession process to be halted. Since then, accession talks have stalled. In July 2017 the EP called for the accession talks not only to be frozen, but also to be suspended. Besides, the EP called for the EU funds allocated to Turkey as an instrument for pre-accession assistance to be conditional on some certain prerequisites. French President, Emmanuel Macron, called for an alternative to accession for Turkey-EU relations in 2018, as Merkel and Sarkozy did before. In this way, not only the EU damaged its credibility deeply, but it also undermined itself by causing Euroscepticism rise around its very borders. This is a situation which should be handled by the EU institutions and politicians very seriously for the sake of the future of Europe. 
Many public opinion surveys revealed that the degree of Euroscepticism in Turkey has been on the rise (Oğuzlu, 2012). The opinion that the accession procedures for the EU membership is not consistently applied and that Turkey is treated unfairly, is speeding increasingly all around the Turkish public (Bürgin, 2012, p.565). What factors could be account for this reversal and up and downs, which have been experienced particularly for the last two decades? There have been quite a number of studies which had searched for the factors mostly account for variation in the attitude of Turkish public opinion toward the EU membership. However, most of these studies were conducted in the 2000s (Çarkoğlu, 2003, 2004; Şenyuva, 2006, 2009; Kentmen 2008). Yet, there still exists need for comprehensive up-to-date analysis, which would contribute to the explanation of the underlying dynamics of the changes of Turkish public attitudes toward the EU, over the years.

Although there exit various studies in search for the fundamental determinants of Turkish public attitudes toward the EU membership as stated before, there does not exist any study focusing on those determinants in connection with the cognitive level of those surveyed. Thus, this article on one side, aims at addressing the basic aspects of the variations in Turkish public support toward the EU and on the other side, is expected to shed light on to what extent the nature of awareness qualities of the respondents, effect on those determinants. For this goal to be achieved, the Eurobarometer data of Turkish public opinion regarding Turkey's EU membership from 2010 to 2018 will be scrutinized. The probable effects of age and gender on the attitudes of public, will also be investigated.

First of all, related literature will be briefly reviewed. Then, Turkey-EU relations will be summarized with respect to the public attitudes toward these developments. Public support for the EU between 2004 and 2018 will be presented. After putting forth the hypothesis, statistical analysis will be conducted using EB survey data from 2010-2018. Finally, empirical results will be manifested and those implications they point out will be discussed in the last section.

\section{Literature Review}

Various approaches have been developed to classify the determinants, which have the capacity to influence public support for the EU membership such as age, gender, education, income level, awareness skills, political values, attachment to nationality and religiosity etc. In this section, among those arguments, not all but some of the most known approaches will be cited. Gabel (1998) is one of the authors, whose arguments are mostly being referred to with regard to the determinants of public support. He found that utilitarian economic concerns were the primary factor in determining the support level of public toward the EU integration. This perspective suggests that public attitudes come out of a cost-benefit calculation with respect to the expected losses and gains associated with the EU membership (Gabel, 1998). With Palmer, he argued that people in different socioeconomic positions were likely to experience various costs and benefits from EU membership and these variances with respect to economic gains and losses would affect these people's attitudes toward integration (Gabel and Palmer, 1995). In other words, they posit that public support for EU membership is positively associated to the cost and benefits which the public is supposed to face. He then found similar findings with Whitten that support for EU membership was positively related to the perceived household financial wellbeing (Gabel and Whitten, 1997). Eichenberg and Dalton (1993) in line with 
these arguments, claimed that personal economic evaluations are positively correlated with the support for EU membership. Anderson $(1998$, p.572) is another scholar attaching importance to the perceived costs and benefits associated with being a member of the EU and support for integration.

The other perspective searching for the basic determinants of support for the EU membership is known as the value approach, which put forward the cognitive mobilization such as political values and perceptions which are constructed on the cognitive skills developed with the awareness of those institutions. Inglehart (1970) primarily argued that as the public's cognitive mobilization increases, because the EU would then become more familiar and less threatening, people will come to a closer position to the European integration (Janssen 1991, p.467). However, he also admitted that, cognitive mobilization was an essential, but not a sufficient condition for supporting the EU. He suggested that the support attitude is mostly related to the quality of the messages in the communication. If those messages predominantly convey negative feelings or assessments, then those more educated would be more likely opposed to integration than less educated. However, he contended that because the EU integration had received favorable coverage in the public opinion in those days, those with a high level of cognitive mobilization would be more likely to favor the integration (Inglehart, 1970, p.47-48).

The political approach contends that people are tend to adopt attitudes toward EU membership, generally in line with the disposition of the party they support (Inglehart, Rabier, and Reif, 1991; Franklin, Marsh, and McLaren, 1994). In other words, political identity and those attitudes attached to this identity is expected to play a significant role in shaping the public attitudes toward the EU membership. Another dimension of this perspective focuses on the relationship between public attitudes toward national governments and the EU. Some authors have argued that electorates tie their support for EU membership to the backing they provide for the national government (Franklin et al., 1995; Anderson, 1998). That is to say, a positive disposition of public on the national government accompanies support for the EU membership respectively (Ehin, 2001; McLaren, 2002).

The political economic approach argues that positive macroeconomic conditions lead public with positive evaluations of government and this disposition supports governments' EU policies (Gabel and Palmer, 1995). On the other hand, there are also opinions, on the contrary, arguing that dissatisfaction with the domestic political system increases the support for EU integration (Sanchez-Cuenca, 2000, p.151). In sum, the evaluation people make regarding their national political system has been found to affect their attitudes toward EU membership in some way, considerably.

As to the relationship between gender and support for the membership, Çarkoğlu (2003) and Kentmen (2008) did not find any meaningful correlation between those two variables. As for religion, although some authors reported that they did not find any meaningful relationship between the religiosity and attitudes toward the EU membership (Kentmen, 2008), nevertheless, Çarkoğlu (2003) argued that, some types of religiosity were likely to be accompanied by some kind of a resistance for the EU membership in Turkey.

Coming to the relationship between "attachment to nationality" and "support for the EU membership", authors mostly agree that nationalist attitudes reduce support for 
EU membership (Kentmen, 2008; Vliegenthart et al., 2008). However, some scholars make a differentiation as to the characteristic of the attitudes regarding nationality. They contend that those national identities, which are exclusive, for example based on a fear from negative influences from the outside of the country, not just reduce the support level but also affect attitudes toward the EU membership negatively (Carey 2002; McLaren 2002; Hooghe and Marks, 2005). McLaren was one of them. She measured the effects of the perception of cultural threat in relation to support for EU integration and found that "fear of others" impacted public opinion toward the EU negatively (McLaren, 2002). Carey (2002) took a step further, adding two new dimensions to "fear of others" as "attachment toward the nation" and "intense feelings for one's country" and found that those three dimensions of variables together affected public attitudes toward the integration negatively. Hooghe and Marks (2005) suggested that an "exclusive national identity" was the strongest factor among others, being negatively related to public support for EU membership. Christin and Trechsel (2002) came to the same conclusion that national identity had a negative effect on public opinion regarding the EU in their study conducted in Swiss.

Within the literature, there is a significant body of work, which focuses on Turkish public attitudes toward Turkey's EU membership, concentrating on mostly three major factors among others as utilitarian considerations, political affiliations and national identity (Wuthricha et al., 2012). For example, Çarkoğlu and Kentmen (2011) found in their study that individuals, who perceive that the EU would positively affect their personal economic circumstances, tend to support the EU membership. Kentmen (2008) contended that "perceived economic prospects" of a probable membership was the strongest indicator of attitudes toward the EU integration among Turkish public. On the other hand, Elgün and Tilman (2007, p.392) found that "perceived cultural threat" has also strong effects on support for EU membership. They argue that those who do not perceive the new supranational institutions as a threat to their nationality are more likely to support the EU integration.

The nomination of Turkey as a candidate country for full membership to the EU at the Helsinki Summit in 1999 brought into question the identity issues with respect to Turkey's membership (Aybar et al., 2007). Kentmen (2008), in her research related to Turkish public opinion toward the EU membership, also found a negative correlation between national identity and support for the EU membership. Another study was the one conducted by Çarkoğlu and Kentmen (2011, p.372-374) who have reached the conclusion that national identity had a significant negative impact on public attitudes toward the EU integration of Turkey, utilizing the two EB survey data 2002/2 and 2003/2.

However, there have also been arguments on the opposite side. For example, Çarkoğlu and Glüpker-Kesebir (2016) suggested in their study that nationalist dispositions were not found to significantly influence public opinion on EU membership in Turkey. Keyman and Aydın Düzgit (2013) also made similar arguments that "fear of losing national identity and sovereignty" was not regarded as a determinant underlying the decline of public support in the post-2005 period (Bürgin, 2012; Kanat, 2010). Yet, their evaluation is stated to be applicable to the period before the accession talks started.

However, some authors remind that those researches mostly assume that respondents are economically rational or reasonably well-informed of the political and economic consequences of the integration (Carey, 2002, p.389; Janssen, 1991; Anderson, 
1998). If this is not the case, in other words if those who have been directed questions, were not sufficiently informed about the EU and aware of the probable consequences of the integration, their answers would not reflect the actual characteristics of the determinants of the support attitude. For instance, it is claimed that usually, public have only a limited understanding of EU policies and their implications (Armingeon and Ceka, 2014 , p.85). Therefore, before directing questions regarding support attitudes toward the membership, it is essential that level of information of those surveyed, about the EU, should be assessed.

In sum, although there have been numerous researches conducted to discover the variations in the Turkish public attitudes toward the membership, they usually focused on the period between 2000 and 2010 . There does not exit any updated study so far involving the years after 2010 until today. Therefore, this study will attempt to fill this gap by including data owing to the period from 2010 to 2018. Additionally, this paper will investigate to what extent the cognitive level of the respondents could explain the variations of the public attitudes toward the EU membership.

\section{Turkey-EU Relations and Public Support}

Turkey-EU relations, date back to Turkey's application for the association to the European Economic Community (EEC) in 1959. In 1963, an association agreement namely Ankara Agreement establishing the framework of the relations between Turkey and the EEC was signed. This agreement entered into force in 1964. In 1970, additional protocol including the regulations on Customs Union was signed and entered into force in 1973. 1987 was the year, Turkey applied for full membership to the European Community. Two years later, European Commission stated that the application was not acceptable until the Commission completed its own internal structural processes.

Turkey-EU Customs Union was entered into force in 1996. Turkey was recognized and declared as a candidate country in 1999 Helsinki Summit. Support for EU membership mounted significantly after this summit up to $74 \%$. The number of studies regarding Turkey's membership has significantly increased from this year forward. In the Copenhagen Summit of December 2002, it is decided that the EU would open accession negotiations with Turkey if it was decided that Turkey met the Copenhagen criteria. This step has paved the way for the opening the accession talks. The level of public support has been stabilized at around $70 \%$ between 2002 and the second half of 2004. Public support for the membership is regarded as to be considerably high until this time.

In December 2004, the European Council, based on the recommendations of the European Commission, decided that Turkey fully satisfied the Copenhagen political criteria. Thus, accession negotiations were decided to launch formally in 2005. Some authors regard this date as the "beginning of the end", after which the enthusiasm of Turkish public toward the EU membership gradually began to decrease (Öniş, 2010). However, this downward trend had already started in the second half of 2004, specifically after the Cyprus Referendum of April 2004. Yaka (2016) labels this referendum as a turning point in terms of the shifting of Turkish public opinion from enthusiasm to disappointment.

Upon the approval of the Annan Plan by the Turkish Cypriots in the April 2004 referenda, the European Council announced that it was "determined to put an end to the isolation of the Turkish Cypriot community" (European Council, 2004). Additionally, the 
EU also encouraged that Turkey's support for the Annan Plan, would stop Cyprus issue no longer to be a problem on the way to Turkey's EU accession. However, the promises made by the EU have never been implemented. Contrarily, the EU continued to pressure Turkey in favor of Greek Cyprus. Having been refused by Turkey on the issues imposed on her for the sake of Greek Cyprus, the EU Council, in December 2006, decided not to open negotiations on eight chapters and not to provisionally close any of the chapters until Turkey met its obligations which were put her shoulders by the EU, regarding Cyprus. Besides, being a member of the EU, Greek Cyprus, as did France, also imposed vetoes on six chapters.

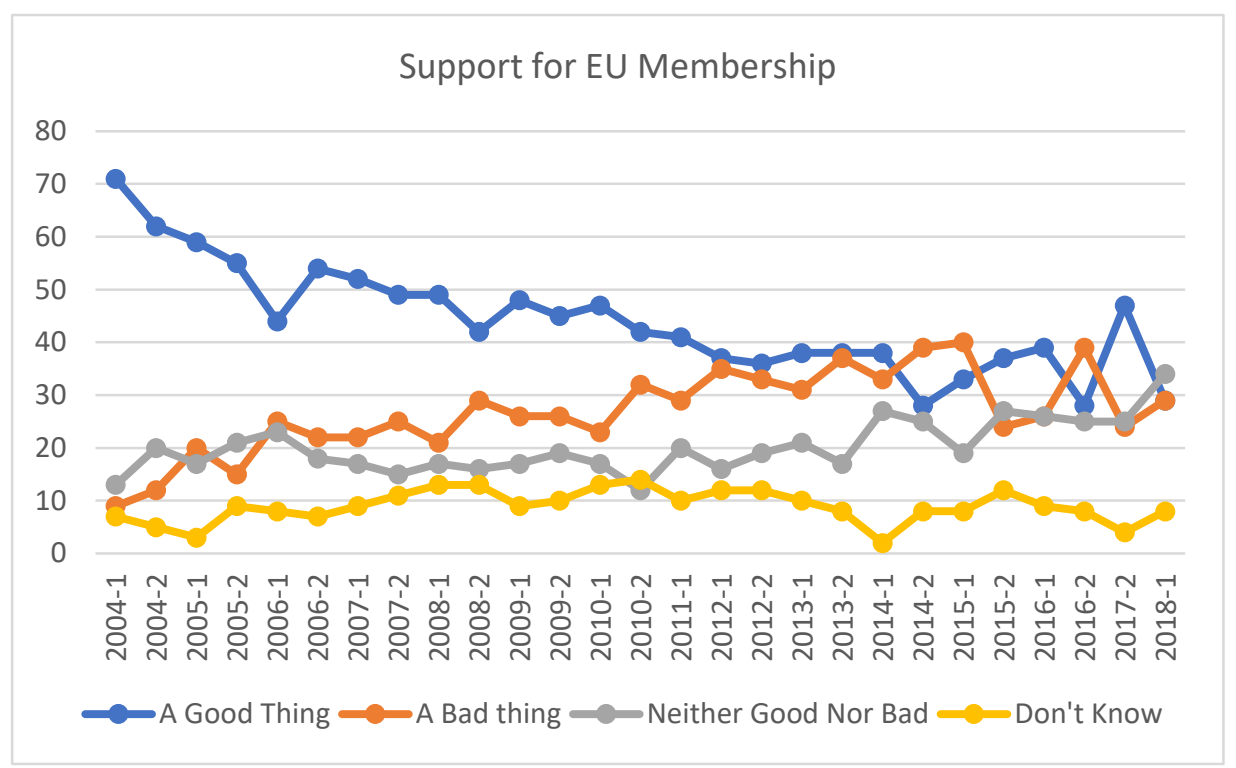

Figure 1. Public Support for EU Membership in Turkey, 2004-2018 Source: Eurobarometer Survey Data

The "absorption capacity" was another topic, which became a key element of the discussions on Turkey's EU membership in 2005 short after the refusal of the proposed Constitutional EU Treaty in France and the Netherlands. After Sarkozy came to power in 2007, the French government blocked Turkey-EU negotiations on five chapters. As the negotiations were blocked in this way step by step, enthusiasm felt by the Turkish public has been rapidly faded away (Yaka, 2016). This situation, not just blocked the accession negotiations but also led Turkish public move away from the EU by creating a perception that the country is not being fairly treated. The Turkish public came to the conclusion that "the Greek Cypriots were rewarded with the EU membership despite their conflict with the plan and the Turkish Cypriots were punished despite their cooperation" (Sözen, 2010). Breaking the promises, treating Turkey unfairly, running the accession processes not objectively and yet freezing the negotiation chapters by the EU led Turkish public 
change their mind and attitude toward the EU. The image of EU thus turned into a body who treats Turkey unfairly, who run the accession process of Turkey not by the objective criteria and who expresses her prejudices and reservations in every instance. While there was the will to be a part of the Union on one hand, on the other hand, there were also the disappointment and mistrust felt by the Turkish public (Yaka, 2016, p.158). Bürgin (2012, p.565) tied this disappointment and frustration also with the ongoing opposition inside the EU against Turkey's accession.

Nowadays, Turkey-EU relations are currently in dire straits not only in terms of pace of negotiations but also, with respect to the mutual falling-out felt by both Turkish public and the EU. It is observed that the percentage of those regarding the EU membership of Turkey as a good thing from the Turkish public, has fallen dramatically from 70's to 30's percent, for the last fifteen years. Moreover, as Figure-1 depicts, a steady negative trend seemed to emerge, with public support declining over the years. In order to capture a wider picture of understanding regarding public support for the EU membership, Eurobarometer (EB) survey data of 2004-2018 is utilized (Figure-1).

The Turkish public support for Turkey's EU membership has been measured by the Eurostat annually or even twice a year, since 2001. Standard Eurobarometer surveys regularly ask respondents in Turkey to indicate whether they would consider a membership of their country in the EU as a good or a bad thing. There have also been a couple of researches conducted by various institutions and scholars since that time. As these studies indicated, the support for EU membership of the Turkish public seems to be highly volatile over the years and has been subject to extreme backlashes (Senyuva, 2018). For instance, according to the EB Survey data, the percentage of Turkish public believing that Turkey joining the EU would be a "good" thing fell from $71 \%$ in 2004 to $44 \%$ in the first half of 2006 and again rose up to $54 \%$ in the second half of the same year. Similar up and downs were experienced in 2008-2009 and 2014-2015. In 2016, the support level fell from $39 \%$ to $28 \%$ and rose up to $47 \%$ in a year and then again fell to $29 \%$ in 2018.

The factors, which have been account for reducing the credibility of the EU in the eyes of Turkish public could be summarized as: the open-ended nature of accession process, the growing opposition of some of the EU politicians to Turkey's membership and disappointment felt by the Turkish public in face of EU's attitudes, which were perceived as double-standard and being far from objectivity. A great deal of literature is available discussing the decreasing public support for the EU membership of Turkey (McLaren, 2007; De Vreese et al., 2008; Öniş, 2010). This paper is one of those attempts, which has aimed at contributing the understanding of the nature of Turkish public support for the EU and the drivers behind this support, particularly for the last decade.

\section{Method}

As the longest running survey regarding the EU in Turkey, going back to 2001, Eurobarometer surveys data enable researchers conduct studies with strong reliability and validity over time. In this study, 9-year of standard EB survey data from 2010 to 2018 were used. The data was obtained from a sample of 9153 person in Turkey with face-toface interview method. Given the size of the sample used, the survey considered as quite representative. Although the intention was an equal distribution by gender, it was revealed 
that $53 \%$ of the participants were male relative to women with a percentage of $46,8 \%$ when the missing $0,2 \%$ was excluded. The data were gathered from those above fifteen years old.

In order to assess the public support toward the EU membership of Turkey, the question of: “Generally speaking, do you think that our country's membership of the European Union would be...?", which the standard EB directs to the participants in order to assess the level of support for the membership, is used. Four types of answers were provided in the EB survey as "a good thing", "neither good nor bad", "a bad thing", and "don't know". We took the answers to this question as dependent variable for it reflects the public support for the EU membership. Replies were coded as 1 (a good thing), 2 (a bad thing). Both "Don't know" and "neither good nor bad" were excluded from our analysis as missing values in order to make the model easy to understand.

Attitudes in face of a probable loss of national cultures and identities, are frequently searched in the context of the EU enlargement. It is generally accepted that for those with a high level of attachment to nationality are supposed to fear that their cultural identities will be lost to some extent with the accession to the EU. Therefore, to find out the attitudes of public regarding nationality, in other words "attachment to nationality", the EB survey question of: "What does the EU mean to you personally?" is preferred. Among the answers "loss of cultural identity" will be considered as an indication reflecting the nationality attachment of public. Therefore, this factor will be taken as an independent variable to search for if it had a meaningful and significant impact on the variation of dependent variable. Answers were coded as 1 (loss of cultural identity), 2 (not mentioned).

"Trust in EU" and "Trust in national government" were the other two determinants included as independent variables in this research. For both the cases, replies were coded as 1 (tend to trust) and 2 (tend not to trust). "Expected benefit" of the membership for the country is the last independent variable, whose effect on the dependent variable will be searched in this paper. The question in the EB Survey was configured as: "Taking everything into account, would you say that (OUR COUNTRY) would benefit or not from being a member of the EU?" Options were cited as "would benefit", "would not benefit" and "don't know". (Would benefit) will be coded as 1 and (Would not benefit) will be coded as 2. Additionally, both the effects of gender and age on the dependent variable will also be investigated.

The research hypothesis will be as follows:

H1: The effects of the determinants of public support for the EU membership varies according to the cognitive level of the respondents.

H2: The utilitarian approach is stronger for those with a high cognitive level, among the participants.

H3: "Attachment to nationality" loses its effect on the public support for the integration, as the cognitive level increases.

H4: The effect of "trust in the EU" on the public support increases as the cognitive level of respondents rises.

\section{Findings}

We preferred to use multinomial logistic regression to test these hypotheses and reveal the effects of determinants on the public support. "A good thing" was coded as reference 
category. Through regression analyses of variables obtained from the data of EB surveys from 2010 to 2018, it is revealed that those having a sense of "loss of cultural identity" with the integration, were more likely tended to have a negative attitude toward the membership. In other words, attachment to nationality is observed to explain the variation in the support for the EU integration significantly.

As to the gender and age, no any significant relationship was detected. The effect of "trust in national government" on the public support was also discovered to be not meaningful. However, as for the variable "trust in EU", it was revealed that there was a meaningful and significant impact on the variation in support attitude toward the integration with the EU (Table-1).

To search for the utilitarian tendencies of the respondents, it is directed to the participants if they regarded being a member of the EU as something beneficial to their country. This factor come out to be the most effective one among the other determinants which apparently could explain the variation in the dependent variable, significantly. That is to say, those tended to believe that their country would benefit from the EU membership are inclined to be more likely to support the integration.

Anderson (1998) put forth that researches generally regard the respondents as rational and well-informed actors who are able to recognize political and economic consequences of the EU membership. However, giving examples from a variety of sources, he argues that empirical evidence disconfirms this assumption (Anderson, 1998: 572). Therefore, as Inglehart (1970, 1977) argued, cognitive mobilization, in other words, level of knowledge about the EU of those surveyed would have an effect both on the support attitudes and determinants of this support. In order to develop an understanding about the information level of respondents regarding the EU, questions directed to the participants whether they were informed about the number of EU member states, the election method of the EP and whether Switzerland was a member state or not, were used.

Table 1 Multinomial Regression Analysis Regarding the Effects of Determinants on the Support for the Integration (Whole sample)

\begin{tabular}{|c|c|c|c|c|c|c|c|c|}
\hline \multicolumn{9}{|c|}{ Parameter Estimates } \\
\hline \multirow{2}{*}{$\begin{array}{l}\text { EU MEMBERSHIP- } \\
\text { GOOD/BAD (CANDIDATES) }\end{array}$} & \multirow{2}{*}{ B } & \multirow{2}{*}{$\begin{array}{l}\text { Std. } \\
\text { Error }\end{array}$} & \multirow{2}{*}{ Wald } & \multirow{2}{*}{ df } & \multirow{2}{*}{ Sig. } & \multirow{2}{*}{$\operatorname{Exp}(B)$} & \multicolumn{2}{|c|}{$\begin{array}{l}95 \% \text { Confidence } \\
\text { Interval for } \operatorname{Exp}(\mathrm{B})\end{array}$} \\
\hline & & & & & & & $\begin{array}{l}\text { Lower } \\
\text { Bound }\end{array}$ & $\begin{array}{l}\text { Upper } \\
\text { Bound }\end{array}$ \\
\hline Intercept & $-2,455$ &, 170 & 208,966 & 1 &, 000 & & & \\
\hline
\end{tabular}


Ç.Ü. Sosyal Bilimler Enstitüsü Dergisi, Cilt 28, Sayı 2, 2019, Sayfa 225-240

\begin{tabular}{|c|c|c|c|c|c|c|c|c|c|}
\hline \multirow{11}{*}{$\begin{array}{l}\text { A } \\
\text { good } \\
\text { thing }\end{array}$} & $\begin{array}{l}\text { [loss of cultural } \\
\text { identity }=1]\end{array}$ &,- 608 &, 123 & 24,486 & 1 &, 000 &, 544 &, 428 & ,693 \\
\hline & $\begin{array}{l}\text { [loss of cultural } \\
\text { identity }=2]\end{array}$ & $0^{\mathrm{b}}$ & . & . & 0 & & . & . & . \\
\hline & $\begin{array}{l}\text { [trust } \\
\text { government=1] }\end{array}$ & , 179 & ,094 & 3,632 & 1 & ,057 & 1,196 & ,995 & 1,438 \\
\hline & $\begin{array}{l}\text { [trust } \\
\text { government=2] }\end{array}$ & $0^{\mathrm{b}}$ & . & . & 0 & . & . & . & . \\
\hline & [trust EU=1] & ,591 & , 101 & 34,170 & 1 &, 000 & 1,805 & 1,481 & 2,201 \\
\hline & [trust EU =2] & $0^{\mathrm{b}}$ & . & . & 0 & & . & . & . \\
\hline & $\begin{array}{l}\text { [expected } \\
\text { benefit=1] }\end{array}$ & 3,945 & ,109 & 1306,43 & 1 &, 000 & 51,683 & 41,729 & 64,011 \\
\hline & $\begin{array}{l}\text { [expected } \\
\text { benefit }=2 \text { ] }\end{array}$ & $0^{\mathrm{b}}$ & . & . & 0 & . & . & . & . \\
\hline & [gender $=1$ ] & ,009 & ,092 & ,009 & 1 & ,925 & 1,009 & 842 & 1,208 \\
\hline & [gender $=2$ ] & $0^{\mathrm{b}}$ & & . & 0 & & & . & \\
\hline & Age & ,004 & ,003 & 1,553 & 1 & ,213 & 1,004 & ,998 & 1,011 \\
\hline
\end{tabular}

Resource: Eurobarometer Survey Data 2010-2018

In 2010, 2011 and 2012, the first question was directed as "The EU currently consists of 27 Member States", in 2017 and 2018, it was directed as "The Euro area currently consists of 19 Member". The second and third questions were the same through 2010 and 2018. With respect to the first and second question, (1) was coded as the correct answer, whereas regarding the third question, the correct answer was coded as (2). With the frequency distribution test, it was revealed that those answered correctly to the questions were $44,5 \%$ for the first question, $39,6 \%$ for the second one, and $36,7 \%$ for the last (Table-4).

Table 2. Level of Knowledge- Questions

For each of the following statements about the EU could you please tell me whether you think it is true or false:

\begin{tabular}{|c|c|c|c|c|}
\hline & & True & False & DK \\
\hline $\mathbf{1}$ & $\begin{array}{l}\text { The EU currently consists of } 28 \text { Member } \\
\text { States }\end{array}$ & 1 & 2 & 3 \\
\hline 2 & $\begin{array}{l}\text { The members of the European Parliament are } \\
\text { directly elected by the citizens of each } \\
\text { Member }\end{array}$ & 1 & 2 & 3 \\
\hline 3 & Switzerland is a Member State of the EU & 1 & 2 & 3 \\
\hline
\end{tabular}

\begin{tabular}{|c|c|c|c|c|c|c|c|}
\hline \multicolumn{2}{|c|}{ Table 3. Level of Knowledge- Descriptive } \\
\hline \multirow{2}{*2}{} & $\begin{array}{c}\text { NUMBER OF } \\
\text { MEMBER } \\
\text { STATES }\end{array}$ & $\begin{array}{c}\text { EP } \\
\text { MEMBERS } \\
\text { SLECTION }\end{array}$ & \multicolumn{2}{c|}{$\begin{array}{c}\text { SWIS MEMBERLAND } \\
\text { IS MER }\end{array}$} \\
& & F & $\%$ & f & $\%$ & f & $\%$ \\
\hline \multirow{2}{*}{ Valid } & True & 4173 & 44,5 & 3716 & 39,6 & 3444 & 36,7 \\
\cline { 2 - 9 } & False & 1808 & 19,3 & 2368 & 25,3 & 2797 & 29,8 \\
\hline
\end{tabular}


Ç.Ü. Sosyal Bilimler Enstitüsü Dergisi, Cilt 28, Sayı 2, 2019, Sayfa 225-240

\begin{tabular}{|l|l|r|r|r|r|r|r|}
\hline & DK & 3376 & 36,0 & 3273 & 34,9 & 3116 & 33,2 \\
\cline { 2 - 8 } & Total & 9357 & 99,8 & 9357 & 99,8 & 9357 & 99,8 \\
\hline Missing & System & 21 &, 2 & 21 &, 2 & 21 &, 2 \\
\hline Total & & 9378 & 100,0 & 9378 & 100,0 & 9378 & 100,0 \\
\hline
\end{tabular}

After having the frequency analysis, it was discovered that the average level of participants knowledge regarding the basic characteristics of the EU, in line with Anderson's (1998) arguments, was quite law. More than half of the participants were lacking of adequate knowledge about the questions.

Table 4. Multinomial Regression Analysis regarding the effects of determinants on the support for the integration (Selected Cases with a high cognitive level)

\begin{tabular}{|c|c|c|c|c|c|c|c|c|c|}
\hline \multicolumn{10}{|c|}{ Parameter Estimates } \\
\hline \multirow{2}{*}{\multicolumn{2}{|c|}{$\begin{array}{l}\text { EU MEMBERSHIP- } \\
\text { GOOD/BAD } \\
\text { (CANDIDATES) }^{\mathrm{a}}\end{array}$}} & \multirow{3}{*}{$\begin{array}{l}\text { B } \\
-3,525\end{array}$} & \multirow{3}{*}{$\begin{array}{l}\text { Std. } \\
\text { Error } \\
, 765\end{array}$} & \multirow{3}{*}{$\begin{array}{l}\text { Wald } \\
21,237\end{array}$} & \multirow{3}{*}{$\begin{array}{l}\text { df } \\
\\
1\end{array}$} & \multirow{3}{*}{$\begin{array}{l}\text { Sig. } \\
, 000\end{array}$} & \multirow{2}{*}{$\operatorname{Exp}(B)$} & \multicolumn{2}{|c|}{$\begin{array}{l}\text { 95\% Confidence } \\
\text { Interval for } \operatorname{Exp}(B)\end{array}$} \\
\hline & & & & & & & & $\begin{array}{l}\text { Lower } \\
\text { Bound }\end{array}$ & $\begin{array}{l}\text { Upper } \\
\text { Bound }\end{array}$ \\
\hline \multirow{12}{*}{$\begin{array}{l}\text { A } \\
\text { good } \\
\text { thing }\end{array}$} & Intercept & & & & & & & & \\
\hline & $\begin{array}{l}\text { [loss of cultural } \\
\text { identity=1] }\end{array}$ &,- 425 & ,413 & 1,063 & 1 &, 303 & ,654 &, 291 & 1,467 \\
\hline & $\begin{array}{l}\text { [loss of cultural } \\
\text { identity }=2]\end{array}$ & $0^{\mathrm{b}}$ & . & . & 0 & . & . & . & . \\
\hline & $\begin{array}{l}\text { [trust } \\
\text { government=1] }\end{array}$ &,- 089 &, 354 &, 063 & 1 &, 802 & ,915 &, 457 & 1,833 \\
\hline & $\begin{array}{l}\text { [trust } \\
\text { government=2] }\end{array}$ & $0^{\mathrm{b}}$ & . & . & 0 & . & . & $\cdot$ & . \\
\hline & [trust EU=1] & 1,443 &, 459 & 9,862 & 1 &, 002 & 4,233 & 1,720 & 10,417 \\
\hline & [trust EU=2] & $0^{\mathrm{b}}$ & . & . & 0 & . & . & . & . \\
\hline & $\begin{array}{l}\text { [expected } \\
\text { benefit=1] }\end{array}$ & 5,093 &, 512 & 98,987 & 1 &, 000 & 162,8 & 59,72 & 444,239 \\
\hline & $\begin{array}{l}\text { [expected } \\
\text { benefit }=2 \text { ] }\end{array}$ & $0^{\mathrm{b}}$ & . & . & 0 & . & . & $\cdot$ & . \\
\hline & [gender=1] &, 071 &, 354 &, 041 & 1 &, 840 & 1,074 &, 537 & 2,147 \\
\hline & [gender $=2$ ] & $0^{\mathrm{b}}$ & . & . & 0 & . & . & . & . \\
\hline & Age &, 011 &, 013 &, 730 & 1 & ,393 & 1,011 & ,985 & 1,038 \\
\hline
\end{tabular}

Resource: Eurobarometer Survey Data 2010-2018

After having the data about the respondent's level of knowledge, those cases, whose answers were correct, were selected from the main data set. The multinomial regression analysis was conducted once again on these selected cases, in order to discover if significance of factors and coefficients were varied from the previous test which was conducted to the whole sample.

With the regression analysis on the selected cases of those with high awareness level, it is revealed that "loss of cultural identity" has not anymore, a meaningful effect 
on the support attitude. As was the case in the previous analysis, "trust in government", gender and age had no any meaningful effect on the dependent variable. However, looking at "trust in EU", it was revealed that this factor was more effective on the dependent variable $(\mathrm{B}=1,443)$ than it was in the prior test $(\mathrm{B}=, 591)$. The similar picture was valid for the factor "expected benefit" $(B=5,093)$, while this coefficient was about $(\mathrm{B}=3,945)$ before.

\section{Conclusion and Discussion}

In this paper, contrary to the previous researches, not only general tendencies affecting on the variation in the public support for the EU was scrutinized, but also the general inclinations of the whole sample and those of the respondents only with high cognitive level was investigated. It was revealed that while "loss of cultural identity" was a meaningful and significant determinant on the variation in the public support for the whole sample, for the selected cases, this factor seemed to have no meaningful impact. Various differences were also observed for the factors "trust in EU" and "expected benefit", between the two analysis. Therefore, $\mathrm{H} 1$ (The effects of the determinants of public support for the EU membership varies according to the cognitive level of the respondents) and $\mathrm{H} 3$ ("Attachment to nationality" loses its effect on the public support for the integration, as the cognitive level increases) were confirmed.

The (B) value of the factor "expected benefit" of the selected cases observed to be significantly higher than that of the whole sample. Therefore, H2 (The utilitarian approach is stronger for those with a high cognitive level, among the participants) was verified. "Trust in EU" is also observed to be more effective on the dependent variable $(\mathrm{B}=1,443)$ than it was in the prior test $(\mathrm{B}=, 591)$. Therefore, $\mathrm{H} 4$ (The effect of "trust in the EU" on the public support increases as the cognitive level of respondents rises) was also confirmed.

Thus, this research produces three main conclusions. First is that, comprising descriptive data regarding public support for the EU integration from a wide span of time, from 2004 to 2018, this paper on one hand provides with updated insight about the variations in the attitudes regarding support for the EU membership, on the other hand it enables comparisons over the long run. Secondly, this paper improves the literature by analyzing the sample according to the cognitive level of the respondents. This method enabled to observe the differences of the effects of determinants on the variation in the support attitude of public, with respect to the level of knowledge.

Lastly, "utilitarian approach" observed to be the strongest factor having a significant impact on the support attitudes of Turkish public for the EU membership. "Trust in EU" also had a meaningful impact on the support. Age, gender and "trust in national government" did not have any meaningful effect. These results seem to be consistent with the earlier findings of the literature. However, as to the "the fear of loss of cultural identity", which is considered to be an indication of "attachment to nationality", while it is found that it had a meaningful and negative impact on the variation of support for the EU membership, as the level of knowledge increased, this relationship observed to be losing its strength and even became insignificant. This is a finding, which has not been observed in the literature, before. 


\section{References}

Anderson, C. J. (1998). When in doubt, use proxies: Attitudes toward domestic politics and support for European integration. Comparative Political Studies 31(5), 569601.

Armingeon, K. and Ceka, B. (2014). The loss of trust in the European Union during the great recession since 2007: The role of heuristics from the national political system. European Union Politics 15(1), 82-107.

Aybar, C., Mergen, A., Perotti, V., and Reid, D. (2007). Analysis of Attitudes of Turkish Citizens towards the Effect of European Union Membership on the Economic, Political, and Cultural Environment. Turkish Studies 8(3), 329-348. Doi:10.1080/14683840701489084.

Bürgin, A. (2012). Disappointment or New Strength: Exploring the Declining EU Support Among Turkish Students, Academics and Party Members. Turkish Studies 13(4), 565-580. Doi:10.1080/14683849.2012.746434.

Carey, S. (2002). Undivided loyalties: Is national identity an obstacle to European integration? European Union Politics 3(4), 387-413.

Çarkoğlu, A. (2003). Who wants full membership? Characteristics of Turkish public support for EU membership. Turkish Studies 4(1), 171-194.

Çarkoğlu, A. and Glüpker-Kesebir, G. (2016). Comparing public attitudes on EU membership in candidate countries: the cases of Croatia, Macedonia and Turkey from 2004 to 2011. Southeast European and Black Sea Studies 16(2), 255-274.

Çarkoğlu, A. and Kentmen, Ç. (2011). Diagnosing Trends and Determinants in Public Support for Turkey's EU Membership. South European Society and Politics 16(3), 365-379. Doi: 10.1080/13608746.2011.598348.

Christin, T. and Trechsel, H. (2002). Joining the EU? Explaining public opinion in Switzerland. European Union Politics 3(4), 415-43.

Cichowski, R. A. (2000). Western dreams, Eastern realities: support for the European Union in Central and Eastern Europe. Comparative Political Studies 33(10), 1243-1278.

De Vreese, C. H., Boomgaarden, H. F. and Semetko, H. A. (2008). Hard and Soft: Public Support for Turkish Membership in the EU. European Union Politics 9(4), $511-$ 530. Doi:10.1177/1465116508095149.

Ehin, P. (2001). Determinants of public support for EU membership: Data from the Baltic countries. European Journal of Political Research 40, 31-56.

Eichenberg, R. C. and Dalton, R. J. (1993). Europeans and the European Community: The dynamics of public support for European integration. International Organization 47, 507-534.

Elgün, Ö. and Erik, R. T. (2007). Exposure to European Union Policies and Support for Membership in the Candidate Countries. Political Research Quarterly 60(3), 391-400.

European Council (2004). European Council Conclusions on Cyprus, 24 April, Brussels.

Franklin, M., Marsh, M. and McLaren, L. (1994). The European Question: Opposition to Unification in the Wake of Maastricht. Journal of Common Market Studies 32, 455-72. 
Franklin, M., Van der Eijk, C. and Marsh, M. (1995). Referendum Outcomes and Trust in Government: Public Support for Europe in The Wake of Maastricht. Western European Politics 18, 101-7.

Gabel, M. (1998). Interests and integration: Market liberalization, public opinion, and European Union. Ann Arbor: University of Michigan Press.

Gabel, M. and Palmer, H. (1995). Understanding variation in public support for European integration. European Journal of Political Research 27, 3-19.

Gabel, M. and Whitten, G. (1997). Economic conditions, economic perceptions, and public support for European integration. Political Behavior 19(1), 81-96.

Hooghe, L. and Gary, M. (2005). Calculation, Community and Cues: Public Opinion on European Integration. European Union Politics 6(4), 419-435.

Inglehart, R. (1970). Cognitive Awareness Mobilization and European Identity. Comparative Politics 3(1), 45-70.

Inglehart, R. (1977). The silent revolution: Changing values and political styles among Western publics. Princeton, NJ: Princeton University Press.

Inglehart, R., Rabier, J., and Reif, K. (1991). The Evolution of Public Attitudes toward European Integration: 1970-86. In: Reif, K. and Inglehart, R. (eds.) Eurobarometer: The Dynamics of European Public Opinion, (pp.135-155). London: Macmillan.

Janssen, J. H. (1991). Postmaterialism Cognitive Awareness Mobilization, and Support for European Integration. British Journal of Political Science 21(4), 443-68.

Kanat, K. B. (2010). AK Party's Foreign Policy: Is Turkey Turning Away from the West? Insight Turkey 12(1), 205-225.

Kentmen, Ç. (2008). Determinants of support for EU membership in Turkey: Islamic attachments, utilitarian considerations and national identity. European Union Politics 9(4), 487-510.

Keyman, E. F. and Aydın-Düzgit, S. (2013). Transforming Turkey-EU Relations: Ground for Hope? In Aydın-Düzgit, S., Duncker, A., Huber, D., Keyman, E. F., and Tocci, N. (Eds.) Global Turkey in Europe: Political, Economic and Foreign Policy Dimensions of Turkey's Evolving Relationship with the EU (pp.275-282). Instituto Affari internazionali (IAI) Research Papers.

McLaren, L. (2002). Public support for the European Union: Cost/benefit analysis or perceived cultural threat? Journal of Politics 64(2), 551-66.

McLaren, L. (2007). Explaining Opposition to Turkish Membership of the EU. European Union Politics 8(2), 251-278.

Oğuzlu, H. T. (2012). Turkey and the European Union: Europeanization Without Membership. Turkish Studies 13(2), 230-241.

Öniş, Z. (2010). Contesting for Turkey's Political 'Centre': Domestic Politics, Identity Conflicts and the Controversy over EU Membership. Journal of Contemporary European Studies 18(3), 361-376.

Sanchez-Cuenca, I. (2000). The political basis of support for European integration. European Union Politics 1(2), 147-171.

Şenyuva, Ö. (2006). Turkish public opinion and European Union membership: the state of the art in public opinion studies in Turkey. Perceptions 11, 19-32. 
Şenyuva, Ö. (2009). Türkiye kamuoyu ve Avrupa Birliği 2001-2008: beklentiler, istekler ve korkular [Turkish public opinion and the European Union 2001-2008: expectations, wishes and fears]. Uluslararası İlişkiler 6(22), 97-124.

Şenyuva, Ö. (2018). Turkish Public Opinion and the EU Membership: between Support and Mistrust. FEUTURE Online Paper, October No. 26.

Slomczynski, K. M. and Shabad, G. (2003). Dynamics of Support for European Integration in Post-Communist Poland. European Journal of Political Research 42(4), 503-39.

Sözen, A. (2010). The Cyprus Question in Turkey-EU Relations. In Tunkrova, L. and Saradin, P. (Eds.) The Politics of EU Accession: Turkish Challenges and Central European Experiences (pp.72-89). Oxon: Routledge.

Vliegenthart, R., Andreas, R. T., Schuck, Hajo G. B. and De Vreese, C. H. (2008). News Coverage and support for European Integration, 1990 - 2006. International Journal of Public Opinion Research 20(4), 415-439.

Wuthrich, F. M., Ardağ, M. M., and Uğur, D. (2012). Politics, cultural heterogeneity and support for European Union membership in Turkey. Southeast European and Black Sea Studies 12(1), 45-62.

Yaka, Ö. (2016). Why Not EU? Dynamics of the Changing Turkish Attitudes Towards EU Membership. Journal of Contemporary European Studies 24(1), 149-170. Doi:10.1080/14782804.2015.1056726. 